\title{
Optimization of Cellulase Production from Bacillus albus (MN755587) and Its Involvement in Bioethanol Production
}

\author{
Emad A. Abada ${ }^{1,4 *}$, Reham M. Elbaz ${ }^{2,4}$, Hana Sonbol $^{3}$, Shereen M. Korany ${ }^{3,4}$ \\ 'Biology Depatrment, Faculty of Science, Jazan University, Jazan, Saudi Arabia \\ ${ }^{2}$ Department of Biology, College of Science, University of Bisha, P.O. Box 551, Bisha 61922, Saudia Arabia \\ ${ }^{3}$ Biology Department, Faculty of Science, Princess Nourah Bint Abdulrahman University, 84428 Riyadh, Saudi Arabia \\ ${ }^{4}$ Botany and Microbiology Dep., Faculty of Science, Helwan University, Cairo, Egypt
}

Received: 16 July 2020

Accepted: 1 November 2020

\begin{abstract}
Worldwide attention has turned to utilize different cellulolytic microorganisms for the bioconversion of cellulose into valuable products, such as bioethanol. The aim of this work is to isolate cellulaseproducing bacteria, optimization the growth conditions, production of bioethanol and possible use in pharmaceutical industry. Twenty cellulase-producing bacterial isolates (Coded alphabetically from A-T) were isolated from Jazan soil. The 'E' isolate showed maximum cellulase production. The isolate was characterized by $16 \mathrm{~S}$ rRNA analysis. The gene sequence of $\mathrm{E}$ isolate indicated that the DNA sequence was $99.6 \%$ homologous with 16S rRNA gene sequences of Bacillus albus. The highest cellulase activity of $B$. albus was achieved when the bacterial growth media was at $\mathrm{pH} 6$, supplemented with glucose, maltose, Carboxy methyl cellulose (CMC), and lactose ( $1 \%, \mathrm{w} / \mathrm{v})$, and inoculated with $3 \%(\mathrm{v} / \mathrm{v})$ and incubated at $35^{\circ} \mathrm{C}$ for $96 \mathrm{~h}$. The results indicate the liberation of $2.0 \mathrm{~g} / 1$ reducing sugar via the DNS method. The total reducing sugar produced was $12.4 \mathrm{~g} / 1$ of ethanol after $72 \mathrm{~h}$, when Saccharomyces cerevisiae was used as a fermentation agent. Large scale production of bioethanol is recommended for possible use in industry.
\end{abstract}

Keywords: carboxy methyl cellulose, cellulase, Bacillus albus, bioethanol

\section{Introduction}

Cellulose, hemicelluloses, and lignin are the main consistent of the lignocellulosic biomass. Cellulose bonds strongly with hemicellulose and lignin [1]. Cellulose $\left(\mathrm{C}_{6} \mathrm{H}_{10} \mathrm{O}_{5}\right)$ appears as a closely packed dense

*e-mail: emadm_abada@yahoo.co.uk structure when crystallized. It comprises thousands of glucose subunits linked by a linear $\beta$-1,4-glycosidic linkage. The efficient usage of the cellulosic wastes products for the economical production of cellulose through the development of sustainable systems has recently gained interest [2]. Worldwide attention has turned to utilize different cellulolytic microorganisms for the bioconversion of cellulose into valuable products, such as alcohol and sugar. The procedure is carried out under high temperature and pressure. Cellulases, a category of glycosyl hydrolases, involving 
endoglucanase, exoglucanase and $\beta$-glucosidase, exhibit distinct enzymatic actions on the breakdown of cellulose [3].

The cellulase enzyme uses cellulose as a substrate and degrades it. Cellulase contains three main constituents (i.e., exoglucanases (EC3.2.1.74), $\beta$-glucosidases (EC 3.2.1.21) and endoglucanases (EC3.2.1.4). The paracrystalline and crystalline structure of cellulose is easily degraded by cellulases. The cellulases obtained from various microbial sources display major difference in their stability, catalytic capacity and cellulose breakdown rate [4]. Due to their adaptability, enormous genetic diversity, ease of genetic manipulation along with short doubling time, the members of the genus have potential to be used in a commercial setup for the synthesis of industrially important biomolecules, e.g. the hydrolysis of cellulose in various industrial processes [1]. Even though, studies conducted on bacterial cellulases and fungal cellulases conclude differently based on their ability to degrade only the synthetic form of carboxymethyl cellulose [5], both target broadly cellulose as a substrate.

Cellulase can be produced from low-cost feedstock such as agricultural wastes e.g a peanut shell, okara, sawdust, a banana peel, rice straw, bagasse, a corncob, a water hyacinth and a sorghum straw by conventional processes. But these conventional processes could lead to dangerous environmental pollution [6]. On the other hand, process variables including $\mathrm{pH}$ value, aeration, inoculums size, and presence of inducers, growth time and temperature impact on the yield and activity of cellulase. It has been reported that cellulose has been employed in a variety of industries such as starch processing, food, malting and brewing, paper/pulp, biofuel production, pharmaceutical, leather industries, and textile and alcoholic beverages [2]. According to the previous information about cellulase and its potential applications in industrial and commercial sectors, this study aspires to isolate and optimize the nutritional conditions for the production of cellulase from the bacterial isolate as well as bioethanol production in coculture with yeast.

\section{Materials and Methods}

\section{Collection of Soil Samples}

Various samples from soil were gathered from Jazan, Sabia and Abu Arish, Jazan, KSA. Pre-sterilized Petri dishes were used to isolate cellulase producing bacteria. Collected soil samples were stored at $4^{\circ} \mathrm{C}$ after being dried, crushed, and filtered.

\section{Isolation and Screening of Cellulase Producing Bacteria}

The collecting soil samples were cultivated on growth media comprising $\mathrm{KH}_{2} \mathrm{PO}_{4} \quad(10 \mathrm{~g} / \mathrm{L})$, carboxymethylcellulose (CMC) (3 g/L), $\left(\mathrm{NH}_{4}\right)_{2} \mathrm{SO}_{4}$ $(0.5 \mathrm{~g} / \mathrm{L})$, yeast extract $(10 \mathrm{~g} / \mathrm{L}), \mathrm{K}_{2} \mathrm{HPO}_{4}(5 \mathrm{~g} / \mathrm{L}), \mathrm{NaCl}$ $(0.2 \mathrm{~g} / \mathrm{L})$, and $\mathrm{MgSO}_{4}(0.1 \mathrm{~g} / \mathrm{L})$ in separate vials, after that, it allowed to grow at $30^{\circ} \mathrm{C}$ for almost $48 \mathrm{~h}$ [7]. Thereafter, they were isolated by plate-streaking methods, plate-pouring, and serial dilution by screening on a nutrient agar media supplemented with CMC with the following composition [agar $(20 \mathrm{~g} / \mathrm{L})$, peptone $(5.0 \mathrm{~g} / \mathrm{L}), \mathrm{CMC}(10 \mathrm{~g} / \mathrm{L})$ with a $\mathrm{pH}$ of $7, \mathrm{NaCl}(3 \mathrm{~g} / \mathrm{L})$, and beef extract $(3.0 \mathrm{~g} / \mathrm{L})$, Congo red] with a $\mathrm{pH}$ of 7. The plates mentioned before were then incubated in a medium of $30^{\circ} \mathrm{C}$ for almost $48 \mathrm{~h}$ by the methods described by Maravi and Kumar [8].

The cellulase activity was quantified visually by culturing bacteria in the growth media containing Cong red dye at $\mathrm{pH}$ of 7.0 followed by incubation at $30^{\circ} \mathrm{C}$ for almost $48 \mathrm{~h}$. The isolate that showed the highest cellulose-degrading capability (qualitative method) of the dye, was selected for further studies and was named the "E isolate".

\section{Preserving the Isolates}

The $\mathrm{E}$ isolate exhibiting maximum production of cellulase enzyme was preserved after obtaining the pure culture on nutritive agar slants and stored at $4^{\circ} \mathrm{C}$ for 2 weeks before being subcultured on new slants.

\section{Morphological and Molecular Identification of the E Isolate}

The E isolate was studied for its morphological and molecular characteristics to assure its identification. The E bacterial isolate was morphologically studied by grown bacterial suspension overnight and Gram staining has been reported by Aslam et al. [9].

\section{Molecular Identification}

Genomic DNA was isolated from the cellulaseproducing strain using the protocol from the Gene Jet Genomic DNA Purification Kit (Thermo). The 16SrRNA gene amplification by PCR was done by using a $16 \mathrm{~S}$ rRNA primer pair named 27F' (5'-AGAGTTTGATCMTGGCTCAG-3'), as reported by Abada et al. and Anahtar et al. [10, 11]. The PCR product was sequenced using an ABI 3730 XL DNA sequencer, 907R (5'-CCGTCAATTCMTTTRAGTTT-3') and the 785F (5'-GGATTAGATACCCTGGTA-3') primers were used for sequencing. The studies on gene homology were done by a BLAST search (http://www.ncbi.nlm. nih.gov/blast/).

\section{Improving Culture Conditions}

During the experiment, the step of improving the growth medium and physiological factors, such as temperature, carbon sources, $\mathrm{pH}$, nitrogen sources, incubation time and inoculums size was carried out 
with step-by-step amendments for the regulating of the cellulase production by the chosen $\mathrm{E}$ isolate.

\section{Effect of Inoculums Concentrations}

The effects of the various inoculums concentrations (e.g. $1 \%, 2 \%, 3 \%, 4 \%$ and $5 \mathrm{v} / \mathrm{v}$ ) of the $\mathrm{E}$ isolate were also monitored in terms of cellulase activity (IU/ml) after $48 \mathrm{~h}$ of incubation.

\section{Effect of Incubation Time}

The $\mathrm{E}$ isolate was grown at different incubation times (e.g 24, 48, 72, 96, and $120 \mathrm{~h}$ ) and the cellulase activity was evaluated.

\section{Effect of Temperature}

The $\mathrm{E}$ isolate was grown at different temperatures (e.g. $20^{\circ} \mathrm{C}, 30^{\circ} \mathrm{C}, 35^{\circ} \mathrm{C}, 40^{\circ} \mathrm{C}$, and $45^{\circ} \mathrm{C}$ ).

\section{Effect of $\mathrm{pH}$}

In order to study the effect of $\mathrm{pH}$ on the cellulase activity, the $\mathrm{E}$ isolate was grown on different $\mathrm{pH}$ values (e.g. 4.0, 6.0, 8.0, 10.0, 12.0).

\section{Effect of Carbon Sources}

The effects of carbon sources such as glucose, maltose, sucrose, CMC, sesame cake, and lactose on the cellulase activity of $\mathrm{E}$ isolate were studied. The substrate concentration was $1 \%(\mathrm{w} / \mathrm{v})$.

\section{Effect of Nitrogen Sources}

The growth medium was annexed with different inorganic and organic nitrogen compounds, like $\left(\mathrm{NH}_{4}\right)_{2} \mathrm{SO}_{4}$, yeast extract, $\mathrm{NaNO}_{3}$, and peptone $1 \%$ (w/v) concentrations, to study their effects on cellulase activity.

\section{Enzyme Assay}

\section{Carboxymethylcellulose Assay}

Carboxymethylcellulose (CMC) was used as a substrate at a concentration of $1 \%$ that dissolved in $0.05 \mathrm{M}$ citrate buffer as described by [12]. The amount of reducing sugar released due to cellulase activity was measured at $540 \mathrm{~nm}$ using the DNS method [13]. One unit of CMCase activity was calculated as $1 \mu \mathrm{mol}$ of glucose liberated per $\mathrm{mL} / \mathrm{min}$.

\section{Saccharification and Fermentation by Co-culture Technique}

To initiate the saccharification process, the cellulose-degrading bacteria were grown in cellulose basal medium at the optimum fermentation conditions with mixing at $120 \mathrm{rpm}$ for 72 hours. The culture was centrifuged, and the supernatant was conditioned for co-culturing with a pure culture of Saccharomyces cerevisiae (Kindly provided by Dr. Nadeem El-Husseiny, National Research Center, Cairo, Egypt). The concentration of ethanol was determined using gas chromatography (Shimadzu-2014, Shimadzu Co. Ltd., Tokyo, Japan) using a packed column

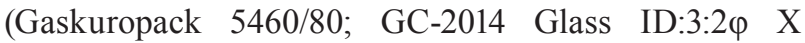
2:1 m, GL Science Co. Ltd., Tokyo, Japan) as reported by [14].

\section{Results and Discussion}

A total of 20 isolates were collected from various soil locations in Jazan regions. Initially, the isolates were examined by Congo red dye, as an indicator for the ability to hydrolyse of cellulose, it appears as a clear zone. Out of all the isolates, just 5 isolates showed cellulase activity (Fig. 1). The highest cellulase activity showed the largest clear zone on Congo red dye was chosen for further study and named temporarily as 'E isolate'.

Cellulase research has primarily focused on fungi but there is growing attention in the production of cellulase by bacteria due to their higher rate of growth, alkali-stable, and thermo-stable properties [15].

A similar technique has been employed previously to select the bacterial isolates that are able to produce cellulase on the basis of clear zone diameter [13]. A variety of cellulolytic microorganisms have been isolated from different environments, such as soil [16]. It has been reported for Bacillus sp. was isolated from molasses [17], Bacillus subtilis, isolated from the cotton industry showed the highest zone of inhibition as well as enzyme activity [18].

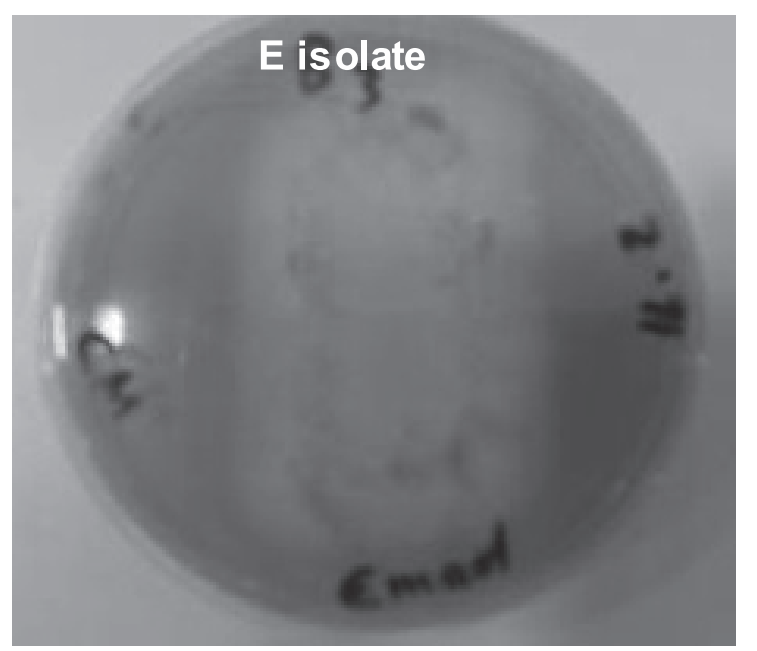

Fig. 1. Cellulase activity by Bacillus albus grown on basal medium contains Congo red dye. The clear zone is an indication of cellulose degradation. 


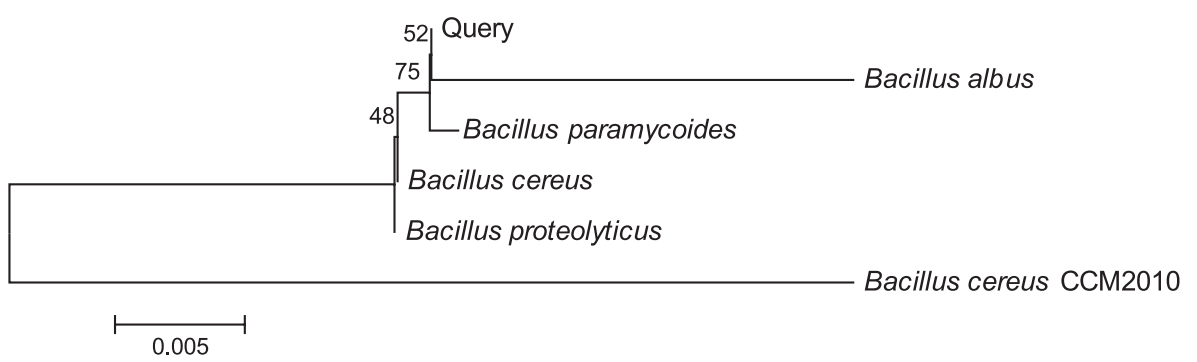

Fig. 2. Phylogenetic tree (Neighbor-joining method) of the 16SrRNA sequence result of Bacillus albus.

\section{Molecular Identification of the E Isolate}

According to both morphological and molecular studies, the maximum cellulase producing isolate was identified. The selected $\mathrm{E}$ isolate acquired on a $\mathrm{CMC}$ agar plate was circular, a white-colored, raised and smooth. When carrying out the Gram staining experiment, the results showed that the $\mathrm{E}$ isolated was Gram-positive bacilli when observed under the microscope with an oil-immersion lens. By 16S rRNA gene analysis, the genomic DNA was separated, purified, and identified. While the gene sequence of the $\mathrm{E}$ isolate was studied to identify similar sequences in the databases (http://www.ncbi.nlm.nih.gov/blast/). The gene sequence alignment of the $\mathrm{E}$ isolate indicated that the DNA sequence was $99.6 \%$ homologous with the 16S rRNA gene sequences of Bacillus albus. Thus, the E isolate was identified as Bacillus albus, as indicated in the phylogenetic tree (Fig. 2). The 16S rRNA sequence has submitted to gene bank under accession number (MN755587). Molecular characterization by 16S rRNA of Bacillus sp. has been reported by Aslam et al. [19]. Based on 16S rRNA sequencing, 60 rhizosphereassociated bacterial isolates belonging to 10 different bacterial genera have been identified (Pseudomonas, Serratia, Hafnia, Enterobacter, Stenotrophomonas, Micrococcus, Bacillus, Xanthomonas, Staphylococcus and Klebsiella) [20]. Although research on Cellulase has been focused on fungi, cellulase production by bacteria has attracted much worldwide attention due to its great growth rate and thermo- and alkali-stable features [21]. Bacillus cellulosilyticus has significant commercial and industrial applications because of its high capability to create alkaline enzymes, such as cellulase [22].

\section{Improving Culture Conditions for Celluase Production}

It was observed that Bacillus albus was the best isolate producing maximum cellulase. To maximize the production of cellulase, many media and culture conditions, such as temperature, nitrogen source, $\mathrm{pH}$, incubation time, carbon source and inoculum size, were improved. The improvement of the media is a powerful parameter in developing fermentation technology, whereas a cost-effective media achieves subsequent cost reductions of the enzymes.

\section{Effect of Incubation Time}

The best incubation time with maximum CMCase activity $(24 \mathrm{IU} / \mathrm{mL}$ ) was at $96 \mathrm{~h}$ (Fig. 3). Cellulase activity was reduced after $96 \mathrm{~h}$ because of the reduction of nutrients or the accumulation of other harmful metabolites in the growth media, that decreasing cellulase activity. It has been reported that the highest cellulase activity of $2.818 \mu \mathrm{g} / \mathrm{mg} / \mathrm{min}$; from Bacillus sp. was achieved after $96 \mathrm{~h}$ [23]. Also, it was shown that the increments in cellulolytic activity were obtained by of B. amyloliquefaciens-ASK11 for 96 h [24].

\section{Effect of Inoculums Concentrations}

The optimum inoculum concentration for maximizing cellulase production of Bacillus albus was $3 \%(\mathrm{v} / \mathrm{v})$, with a maximum CMCase activity of $19 \mathrm{IU} / \mathrm{mL}$, respectively (Fig. 4). The enzyme activity decreased when added with higher inoculums concentration. The microbial growth slowed, because of the competition for nutrients and oxygen amongst the cells. The previously mentioned factors likewise affect the longevity of the stationary phase that leads to a decrease in enzyme activity because of the accumulation of secondary metabolites and toxic products. It has been reported similar results regarding maximum cellulase production at an inoculum size of $3 \%(\mathrm{v} / \mathrm{v})$. The maximum CMCase activity was $19 \mathrm{IU} / \mathrm{mL}$ from Bacillus cereus [25]. It has been shown that the inoculums size of $3 \%$ was best for cellulase

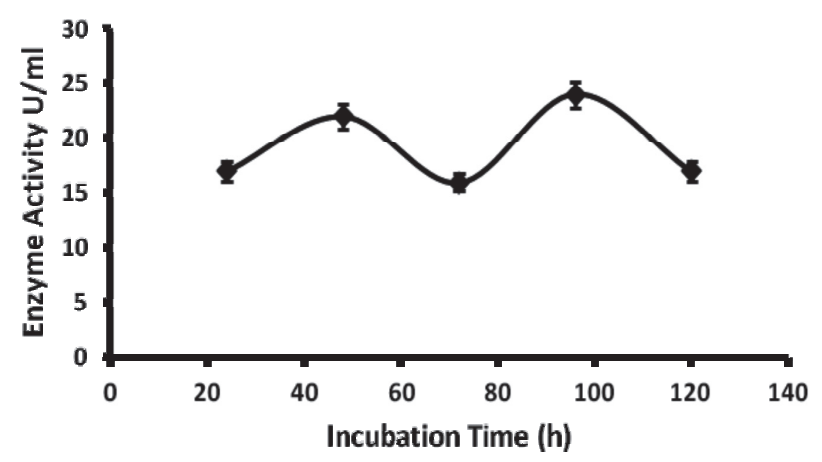

Fig. 3. Effect of incubation time on cellulase production by Bacillus albus. 


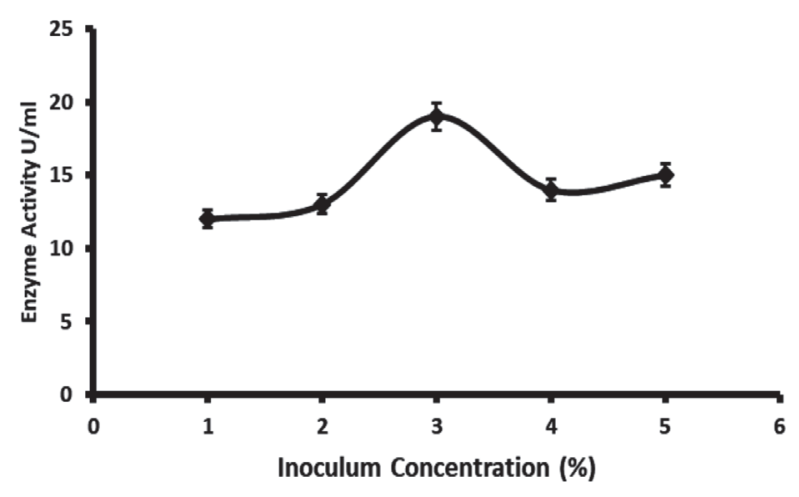

Fig. 4. Effect of inoculums concentration on cellulase production by Bacillus albus.

production by Bacillus sp. [26]. Also, inoculums size of $3 \%$ has been proofed for maximum cellulase production by Bacillus subtilis [27]. On the contrary to our results, Bacillus subtilis BY-2 showed maximum cellulase production with inoculums size of 4\%. [28].

\section{Effect of Temperature}

The temperature has a significant role in the enzyme activity and physiology of microorganisms. Accordingly, different temperatures ranging between $\left(20^{\circ} \mathrm{C}\right.$ and $\left.45^{\circ} \mathrm{C}\right)$ were used for the incubation of Bacillus albus cells for $96 \mathrm{~h}$ to study the effect of temperature on enzyme activity. It was noticed that the maximum CMCase activity of $6 \mathrm{IU} / \mathrm{mL}$ at $35^{\circ} \mathrm{C}$, which was partly decreased to $4 \mathrm{IU} / \mathrm{mL}$ at $45^{\circ} \mathrm{C}$ (Fig. 5). By increasing the temperature was increased above the $35^{\circ} \mathrm{C}$, the enzyme activity was reduced due to the denaturation of the enzyme; therefore, the lowest enzyme activity was achieved above $45^{\circ} \mathrm{C}$. Comparatively, the cellulase of Bacillus pumilis showed the highest activity when it has grown at $35^{\circ} \mathrm{C}$ [29]. Recently, it was demonstrated that the best temperature for chitinase production by Bacillus laterosporus was at $35^{\circ} \mathrm{C}$ [30]. Our results disagree with those of Radulovic et al. [31] as they found the maximum temperature for cellulase activity was $30^{\circ} \mathrm{C}$.



Fig. 5. Effect of temperature on cellulase production by Bacillus albus.

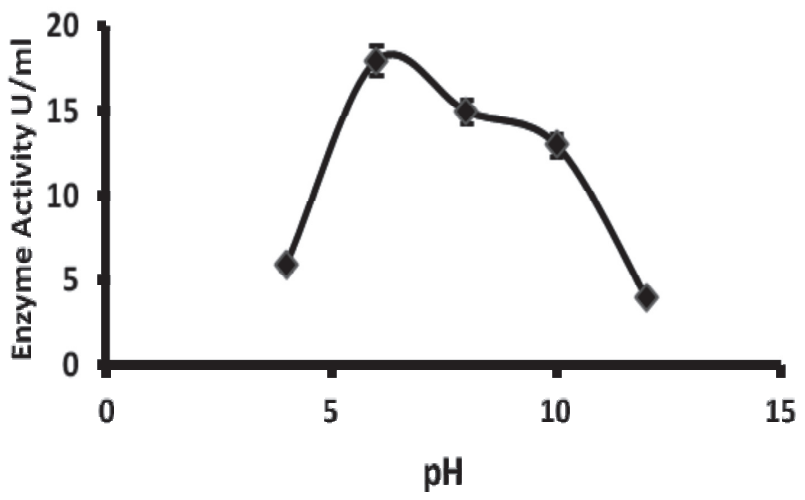

Fig. 6. Effects of initial $\mathrm{pH}$ of the media on cellulase production by Bacillus albus.

\section{Effect of $\mathrm{pH}$}

To study the effect of different $\mathrm{pH}$ values on the cellulase activity of Bacillus albus, different $\mathrm{pH}$ ranged from 4.0 to 12.0 were used. The optimum $\mathrm{pH}$ for highest cellulase activity was achieved at $\mathrm{pH} 6$ with CMCase activity of $(18 \mathrm{IU} / \mathrm{mL})$; while the lowest CMCase activity of $6 \mathrm{IU} / \mathrm{mL}$ at $\mathrm{pH}$ 4. (Fig. 6). $\mathrm{pH}$ is necessitated to preserve the $3 \mathrm{D}$ - shape of the catalytic sites of the enzyme, and a variation in $\mathrm{pH}$ values results in alterations in its ionic bonding due to the loss of functional shape. The optimal $\mathrm{pHs}$ of Clostridium thermocellum was 5.7 to 6.1 [32]. Also, cellulase of Bacillus cellulosilyticus showed optimum $\mathrm{pH}$ of 5.0 as reported by Sreena and Sebastian [33]. Moreover, the optimum $\mathrm{pH}$ of purified cellulase of Bacillus $\mathrm{sp}$. was $\mathrm{pH}$ $6.0[34]$.

\section{Effect of Carbon Sources}

It was observed that the best environment to grow cellulolytic Bacillus albus was at $35^{\circ} \mathrm{C}$ for $96 \mathrm{~h}$ in a growth media with a pH of 6 including $\mathrm{K}_{2} \mathrm{HPO}_{4}(5 \mathrm{~g} / \mathrm{L})$, $\left(\mathrm{NH}_{4}\right)_{2} \mathrm{SO}_{4}(0.5 \mathrm{~g} / \mathrm{L})$, yeast extract $(10 \mathrm{~g} / \mathrm{L}), \mathrm{KH}_{2} \mathrm{PO}_{4}$ $(10 \mathrm{~g} / \mathrm{L}), \mathrm{NaCl}(0.2 \mathrm{~g} / \mathrm{L})$ and $\mathrm{MgSO}_{4}(0.1 \mathrm{~g} / \mathrm{L})$ with a $\mathrm{pH}$ of 6 in combination with different carbon sources, like glucose, lactose, maltose, sucrose, CMC and sesame cake with concentration of $1 \%(\mathrm{w} / \mathrm{v})$ to study their effect(s) on cellulase activity of Bacillus albus. The addition of glucose, maltose, CMC, and lactose to medium helped in achieving the maximum CMCase activity (132 IU/mL) (Fig. 7). Similar results [32] mentioned that lactose was the best carbon source for the ideal cellulose production for B. subtilis. Bushra et al. [35] concluded that CMC played an important role in the cellulase activity of Bacillus sp., while Teodoro et al. [36] found that maltose was the best carbon source for Bacillus sp. Thus, the past studies didn't find an ideal carbon source for the production of cellulases for the given set of culture conditions. 


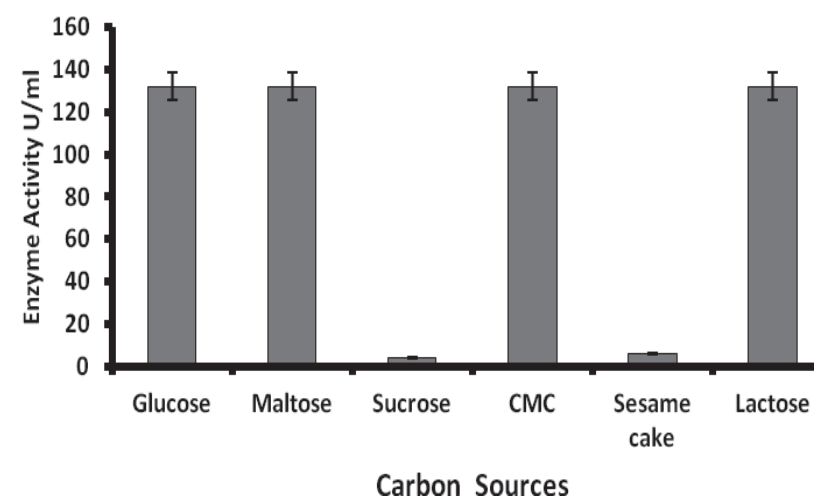

Fig. 7. Effect of different carbon sources $(1 \%$, w/v) on cellulase production by Bacillus albus.

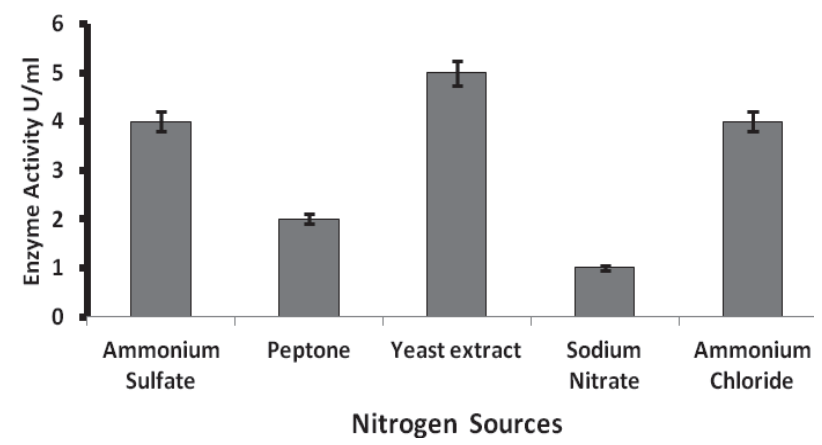

Fig. 8. Effect of different nitrogen sources (1\%,w/v) on cellulase production by Bacillus albus.

\section{Effect of Nitrogen Sources}

The effects of different nitrogen sources, such as yeast extract, $\mathrm{NaNO}_{3},\left(\mathrm{NH}_{4}\right)_{2} \mathrm{SO}_{4}$, and peptone each at $1 \%(\mathrm{w} / \mathrm{v})$ concentrations in the media, were studied on cellulase production, at $96 \mathrm{~h}$ of incubation. The maximum CMCase activity of $5 \mathrm{IU} / \mathrm{mL}$ for the media supplemented with yeast extract. For the optimum cellular growth and utilization of nutrients, it is necessary to supplement an external nitrogen source in the fermentation media throughout extracellular enzyme production (Fig. 8). Furthermore, it was concluded that the use of organic nitrogen sources is more suitable for maximum cellulase production compared with inorganic sources $[37,38]$. It has been reported that the maximum cellulase activity of Bacillus subtilus MUS1 was achieved with yeast extract [39]. Some organic and inorganic compounds present in the yeast extract will possibly induce the production of extracellular enzyme production [40].

\section{Production of Bioethanol via the Saccharification and Fermentation by Co-culture Technique}

The saccharification process liberated $2.0 \mathrm{~g} / 1$ of the reducing sugars, as measured by the DNS method (data not shown). The bioethanol was produced using a coculture of Saccharomyces cerevisiae and Bacillus albus in the optimized fermentation medium. An analysis of the fermentation medium via GC-MS revealed the $12.4 \mathrm{~g} / 1$ content of ethanol (Fig. 9).

Our results indicated a higher concentration of ethanol was obtained, when Bacillus albus was used to degrade $\mathrm{CMC}$, suggesting a higher substrate conversion to reducing sugars. It is worth mentioning that enzymatic hydrolysis is done by cellulase enzymes that are highly substrate-specific. The obtained ethanol yield can be compared with that of the yield acquired by other wild-type bacteria as reported by Banerjee et al. [41]. The maximum obtained ethanol concentration of $3.5 \mathrm{~g} / 1$ was found by the wild-type Caldicellulosiruptor DIB 004C as assured by Svetlitchnyi et al. [42]. Whereas other studies demonstrate that an optimized medium helps in increasing a bioethanol production of $4 \mathrm{~g} / 1$ by the wild-type Clostridium thermocellum strain I-1-B and optimizing it to $23.6 \mathrm{~g} / 1$ ethanol yield by the same strain [43]. It was found that the bioethanol yield achieved in their study was higher compared with the yield $(7.5 \mathrm{~g} / \mathrm{L})$ acquired from the fermentation of

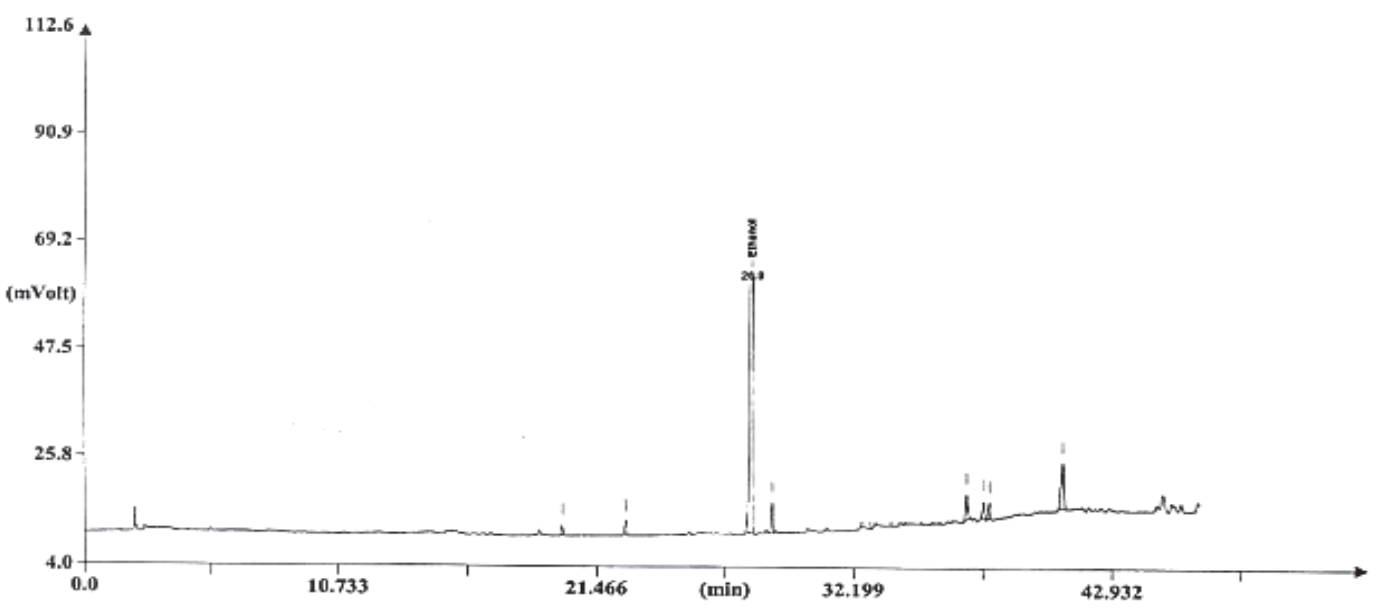

Fig. 9. Chromatogram of ethanol produced by co-culture of Bacillus albus and Saccharomyces cerevisiae. 
sugarcane bagasse hydrolysate using Pichia stipitis DSM 3651. Additionally, It was mentioned that the yield of the co-culture was lower compared with the reported yield of the banana pseudostem (17 g/l) [44].

\section{Possible Application of Bioethanol in Pharmaceutical Products}

Ethanol is used in oral, parenteral, and topical (including inhalational) prescription and nonprescription drug products as an active ingredient. While it is mainly used to help solubilize several drugs due to its solvent properties, it also has many pharmacological concentration-dependent actions, including sedative, carminative, cooling, antipyretic, rubefacient, washing, and antiseptic properties. Concentrations of $40 \%$ or more could be found in various oral preparations, thus resulting in patients consuming a significant amount of alcohol through the course of the day. Also, alcohol can be found in a wide range of cosmetic products such as body lotions, after shave or fragrances. Heren, we strongly recommend large sacle production of bioethanol by fermentation of microorganisms to be used in pharmaceutical industry.

\section{Conclusion}

To enhance cellulose enzyme production, the bacterial growth conditions were optimized. Our results indicated that the cellulase activity of Bacillus albus was improved by optimizing the different growth and cellulase production parameters. In addition, the maximum concentration of ethanol produced in the fermentation medium was $(12.3 \mathrm{~g} / \mathrm{l})$, after $72 \mathrm{~h}$, estimated by GC-MS analysis, when a co-culture of Saccharomyces cerevisiae and Bacillus albus was employed. To the best of our knowledge, our study is the first to demonstrate the efficient production of bio-ethanol by applying a co-culture strategy involving the continuous fermentation and saccharification of CMC from the Jazan region. Our results strongly recommend large sacle production of bioethanol by ferementation of microorganisms to be used in industry.

\section{Acknowledgment}

This research was funded by the Deanship of Scientific Research at Princess Nourah bint Abdulrahman University through the Fast-track Research Funding Program.

\section{Conflict of Interest}

The authors declare that they have no competing interests.

\section{Refrences}

1. SETHI S., DATTA A., GUPTA B.L., GUPTA S. Optimization of cellulase production from bacteria isolated from soil. ISRN biotechnology, 2013.

2. BHAT M.K. Cellulases and related enzymes in biotechnology. Biotechnol. Adv. 18, 355, 2000.

3. YANG W., MENG F., PENG J., HAN P., FANG F., MA L. Isolation and identification of a cellulolytic bacterium from the Tibetan pig's intestine and investigation of its cellulase production. Electronic J. Biotechnol. 17, 262, 2014.

4. SINDHU R., KUTTIRAJA M., BINOD P., SUKUMARAN R.K., PANDEY A. Bioethanol production from dilute acid pretreated Indian bamboo variety (Dendrocalamus sp.) by separate hydrolysis and fermentation. Ind.Crop.Prod. 52, 169, 2014.

5. NAGAIAH P., NELLAIAPPAN O., POLPASS A.J., RANGASAMY A., SOON-WO K. Optimization of cellulase production by Enhydrobacter sp. ACCA2 and its application in biomass saccharification. Front. Microbiol. 6, 1046, 2015.

6. MORALES M.A.M., HERNANDEZ J.L.M., GARZA H., AGUILAR C.N. Cellulolytic enzymes production by solid state culture using pecan nut shell as substrate and support. Am. J. Agri. Biol. Sci. 6 (2), 196, 2011.

7. ACHARYA A., JOSHI D.R., SHRESTHA K., BHATTA D.R. Isolation and screening of thermophilic cellulolytic bacteria from compost piles. Sci. World J. 10, 43, 2012.

8. MARAVI P., KUMAR A. Iolation, screening and identification of cellulolytic bacteria from soil. Biotech. J. Inter. 24 (1), 1, 2020.

9. GRAM C. Ueber die isolirte Firbung der Schizomyceten iu Schnitt-und Trockenpriparaten. Fortschr. Med. 2, 185, 1884.

10. ABADA E., MASRAHI Y., AL-ABBOUD M., ALNASHIRI H., EL-GAYAR K. Bioethanol production with cellulose enzyme from Bacillus cereus isolated from sesame seed residue from the Jazan region. BioRes. 13 (2), 3832, 2018.

11. ANAHTAR M.N., BOWMAN B.A., KWON D.S. Efficient nucleic acid extraction and 16SrRNA gene sequencing for bacterial community characterization. J. Visualized Expts. 110, 1, 2016.

12. MANDELS, M., WEBER W. The production of cellulases. In: Cellulases and their applications. A Symposium. GJ Hajny, ET Resse (ed.) American Chemical Society Advanced Series 95, 391, 1969.

13. MILLER G.L. Use of dinitrosalicylic acid reagent for determination of reducing sugar. Anal. Chem. 31, 426, 1959.

14. IRE F.S., EZEBUIRO V., OGUGBUE C.J. Production of bioethanol by bacterial co-culture from agro-wasteimpacted soil through simultaneous saccharification and co-fermentation of steam-exploded bagasse. BIOB. 3 (26), $1,2016$.

15. SADHU S., MAITI T.K. Cellulase Production by Bacteria: A Review. British Microbiol. Res. J. 3 (3), 235, 2013.

16. DANTUR K.I., ENRIQUE R., WELIN B., CASTAGNARO A.P. Isolation of cellulolytic bacteria from the intestine of Diatra easaccharalis larvae and evaluation of their capacity to degrade sugarcane biomass. AMB Exp. 5, 15, 2015

17. RASUL F., AFROZ A., RASHID U., MEHMOOD S., SUGHRA K. Screening and characterization of cellulase 
producing bacteria from soil and waste (molasses) of sugar industry. Int. J. Biosci. 6, 230, 2015.

18. GAUTAM R., SHARMA J. Optimization, purification of cellulase produced from Bacillus subtilis subsp. inaquosorum under solid state fermentation and its potential applications in denim industry. Int. J. Sci. Res. 3, 1759, 2012.

19. ASLAM S., HUSSAIN A., QAZI J.I. Production of cellulase by Bacillus amyloliquefaciens-ASH11 under high chromium stress. Waste Biomass Valorization 10, 53, 2019.

20. HAMA C., BOUREIMA K., ADAMA S., ABEL T., GASTON S., YVES T., IVETTE I.L.O., ALY S. Molecular characterization of Bacillus, lactic acid bacteria and yeast as potential probiotic isolated from fermented food. Sci. African 6, 1, 2019.

21. SADHU S., MAITI T.K. Cellulase Production by Bacteria: A Review. British. Microbiol. Res. J. 3 (3), 235, 2013.

22. HORIKOSHI K. Production of alkaline enzymes by alkalophilic microorganisms. Part I. Alkaline protease produced by Bacillus no. 221. Agric. Biol. Chem. 36, 1407, 1971.

23. DAS A., BHATTACHARYA S., MURALI L. Production of cellulase from thermophilic Bacillus $s p$. isolated from cow dung. AM. Eurasian. J. Agric. Environ. Sci. 8, 685, 2010.

24. MOHAMMED A.F. Optimization of cellulase and chitinase enzymes production by plant growth promoting rhizobacteria. Novel Res. Microbiol. J. 4 (1), 641, 2020.

25. AHMAD B., NIGAR S., SHAH S.S.A., BASHIR S., ALI J. Isolation and identification of cellulose degrading bacteria from municipal waste and their screening for potential antimicrobial activity. World Appl. Sci. J. 27, 1420, 2013.

26. NEHAD E.A., YONESS M.F., REEM A.A. Optimization and purification of cellulase produced by Penicillium decumbens and its application. Egy. Pharm. J., 18 (4), 391, 2019.

27. YANG W., MENG F., PENG J., HAN P., FANG F., MA L., CAO B. Isolation and identification of a cellulolytic bacterium from the Tibetanpig's intestine and investigation of its cellulase production. Electron J. Biotechnol. 17, 262, 2014.

28. GAUTAM R., SHARMA J. Production and optimization of alkaline cellulase from Bacillus subtilis in submerged fermentation. Int. J. Sci. Res. 3, 1186, 2014.

29. KANMANI R., VIJAYABASKAR P., JAYALAKSHMI S. Saccharification of banana-agro waste and clarification of apple juice by cellulase enzyme produced from Bacillus pumilis. World Appl. Sci. J. 12 (11), 2120, 2011.

30. SRIARIYANUN M., TANTAYOTAI P., YASURIN P., PORNWONGTHONG P., CHEENKACHORN K. Production, purification and characterization of an ionic liquid tolerant cellulase from Bacillus $s p$. isolated from rice paddy field soil. Electron. J. Biotechnol. 19 (1), 23, 2016.

31. RADULOVIC O., PETRIV M., RASPOR M., STANOJEVIC O., JANAKIEV T., TADIC V., STANKOVIC S. Assessment of Bacterial phenol-
resistance:Plant/Bacteria system for potential bioremediation-partII. Pol. J. Environ. Stud. 28 (2), 811, 2019.

32. WANG J., HUA B., WANG X., CUI Z. Characteristics of cellulase in cellulose-degrading bacterium strain Clostridium straminisolvens (CSK1). Afr. J. Microbiol. Res. 11 (10), 414, 2017.

33. SREENA C.P., SEBASTIAN D. Augmented cellulase production by Bacillus subtilis strain MU S1 using different statistical experimental designs. Genet. Eng. Biotechn. 16, 9, 2018.

34. WITA A., BIALAS W., WILK R., SZYCHOWSKA K., CZACZYK K. The influence of temperature and nitrogen source on cellulolytic potential of microbiota isolated from natural environment. Pol. J. Microbiol. 68, 105, 2019.

35. BUSHRA M., ABDUL Q., ZAMEER M., AHMAD A.R., NELOFER R., JAMIL N., ARZOO S., AFZAAL R. Production of cellulases by Bacillus cellulosilyticus using lignocellulosic materials. Pol. J. Environ. Stud. 27 (6), 2659, 2018

36. TEODORO C.E.S., MARTINS M.L.L. Culture conditions for the production of thermostable amylase by Bacillus $S p$. Braz. J. Microbiol., 31 (4), 298, 2000.

37. GOYAL V., MITTAL A., BHUWAL A.K., SINGH G., YADAV A., AGGARWAL N.K. Parametric optimization of cultural conditions for carboxymethyl cellulase production using pretreated rice straw by Bacillus $s p$. 313SI under stationary and shaking conditions. Biotechnology research international, 2014.

38. SINJAROONSAK S., CHAIYASO T., H-KITTIKUN A. optimization of cellulase and Xylanase production by Streptomyces thermocoprophilus TC13W using low cost pretreated oil palm empty fruit bunch. Waste Biomass Valorization 11, 3925, 2020.

39. TABSSUM F., IRFAN M., SHAKIR H.A., QAZI J.I. RSM based optimization of nutritional conditions for cellulase mediated saccharification by Bacillus cereus. J. Biol. Eng. 12, 7, 2018.

40. NANDIMATH, A.P., KHARAT, K.R., GUPTA, S.G., KHARAT, A.S. Optimization of cellulase production for Bacillus sp. and Pseudomonas sp. soil isolates. Afr. J. Microbiol Res. 10, 410, 2016.

41. BANERJEE S., MUDLIAR S., SEN R., GIRI B., SATPUTE D., CHAKRABARTI T. Commercializing lignocellulosic bioethanol: technology bottlenecks and possible remedies. Biofuel Bioprod. Bior. 4, 77, 2010.

42. SVETLITCHNYI V., KENSCH O., FALKENHAN A.D., KORSESKA G.S., LIPPERT N. Single-step ethanol production from lignocellulose using novel extremely thermophilic bacteria. Biotechnol. Biofuels 6 (1), 31, 2013.

43. KLEIN-MARCUSCHAMER D., OLESKOWICZ-POPIEL P., SIMMONS B.A., BLANCH H.W. The challenge of enzyme cost in the production of lignocellulosic biofuels. Biotechnol. Bioeng. 109, 1083, 2012.

44. INGALE S., JOSHI J.S., GUPTE A. Production of bioethanol using agricultural waste: banana pseudo stem. Braz. J. Microbiol., 45, 885, 2014. 